\title{
Chapter 7 \\ Imagining future traditions: Strategies in popular culture spaces
}

\begin{abstract}
The Raptivismo (Rap + activismo, activism) radio show is on the air for its weekly 2-hour slot on a Sunday. In the second story of a building near the center of Juchitán I'm in the room which serves as a small local radio studio with 7 young men, sitting around a table which supports 3 microphones on small tripods. The host of the show is Juchitán-native Dalthon Pineda, who is a primary school teacher and a writer in addition to being a proponent of hip-hop music and culture. He interviews several rappers who are in the studio, including Cosijopi Ruiz López and Antonio Sánchez Ruiz of the Juchitán-based group Juchirap, and a rapper visiting from Puerto Escondido, a few hours away up the coast. The show and the side conversations in the studio are in Spanish; the music that is played and discussed is in Spanish and Zapotec. They take calls from listeners and offer a free $\mathrm{CD}$ to the first caller.
\end{abstract}

In a break, the host tells me about the first time a group of them performed rap at a public event and were met with animosity from politicians and members of the public, who associate hip-hop with vandalism and violent urban culture. He says it has been a challenge to show people that they do 'rap consciente', conscious rap, which takes up important social issues and promotes critical thinking. One of the rappers in the studio agrees, saying that older people think rap is about gangsters, until they hear that you're rapping in Zapotec- then they shake your hand and ask where they can get your music. Two years ago (2012) one of the first people to rap in Isthmus Zapotec, Vicente Ramírez Santiago, or Rosty, won a prestigious state-level award for Indigenous language writing for his rap lyrics, which remains an important mark of legitimacy and pride for the local hip-hop community. The Juchirap group recounts how they've been invited to perform in several schools now and received an enthusiastic response from the students and a warm welcome from the teachers. Tomorrow they'll perform at 7am in a secondary school in the southern neighborhood of Juchitán, where most people speak Zapotec.

On the air, the host asks the group about the bilingual (Spanish-Zapotec) lyrics of one of their songs, which includes a reference to Juchitán poet Gabriel López Chiñas. At several points the young musicians talk about festivals and events that they have participated in elsewhere in Mexico, and the support and mentors that they have from being part of wider hip-hop networks. Towards the end of the show an adolescent boy and girl arrive at the studio, somewhat timid; they're the callers who have come to claim their free CD. The Juchirap members sign the CD for them, and do a fist-bump handshake with the boy before the teenagers leave.

(Field notes July 2014)

Popular culture spaces such as this radio show are important domains of language use where norms of communication and identities are negotiated. The forms of music, visual art and literature that are created and shared through mass media, and increasingly through social media, can also have a significant 
impact on language ideologies. The Isthmus is home to artists of many genres of music and visual art, as well as the literary heritage discussed in chapter 6 . While language activism is not the foremost goal of all of these artists, Isthmus Zapotec does feature prominently for some of them. In the case of the young rappers participating in the Raptivismo show, the displacement of Zapotec is one of the many social changes that they observe and comment on through rap; increasing insecurity and violence in their communities, and political corruption are also prominent concerns. The fact that the local hip-hop community had secured a space on the air and had an audience for their program was evidence that they were well on the way to being accepted as a legitimate art form and youth movement. They were conscious of participating in a transnational music culture, discussing their wider networks and influences, in addition to wearing an internationally-recognizable style of clothes and performing other indexes of hip-hop-ness, such as the stylized handshake. At the same time, they were also keen to reach the ears and minds of their peers and neighbors in the Isthmus, and an (old-fashioned) handshake with someone who was previously skeptical but came to be interested in their music was viewed as an achievement. The use of Diidxazá was often discussed as part of what attracted listeners and attention locally, in part because it was an unexpected fusion of something viewed as a foreign, urban, modern art form with something viewed as local, largely rural, and traditional. For the rappers and their listeners, this fusion was also a congruent reflection of their everyday lives, where all of these elements were current and relevant. Most of young hip-hop artists had a foot in local traditions as well as global trends; one continued to play in the "prehispanic' music group ${ }^{32}$ he had participated in since he was young; another occasionally worked with his father painting banners for the Velas, saints' festivals, but was also an avid graffiti painter. They knew how to shake hands in both old and new ways.

In this chapter I examine several popular culture spaces which have grown to be important domains for language activism in the Isthmus, including groups which organize events and performances, participation in digital spaces, and the wider networks of civil society organizations that sometimes support local initiatives. These popular culture initiatives are important spaces where socialization and learning occur without the oversight or intervention of formal or informal educators (7.1). The amount of locally organized groups, collectives, events, and

32 'Prehispanic music', as played for some public occasions in the Isthmus, consists of drumming, turtle-shell percussion, and a whistle instrument. 
digital resources that are created in the Isthmus is prolific; describing even a fraction of these initiatives would require a book in and of itself. Here, I highlight examples of some of the initiatives I observed, noting that there are many inspiring initiatives which unfortunately remain unmentioned here for lack of space and time. Rather than attempt to inventory popular culture initiatives, I focus on several key activism strategies which are shared among multiple initiatives (7.2). Salient language activism strategies among popular culture initiatives include creating events, such as performances and festivals, and creating semi-fluid and participatory spaces or structures, such as a yearly writing competition, a radio show, and a social media page. Through these spaces and events, activists are representing their own identities and communication practices as both local and global, and both traditional and modern. I conclude with a summary of the language activism strategies in popular culture spaces, which remain fluid, highly creative and diverse as they recontextualize Isthmus Zapotec in a changing language ecology and society (7.3).

\subsection{Negotiating social meanings through popular culture activism}

Language activism has often been pursued through artistic, popular culture and media channels. These domains lend themselves to an especially flexible and negotiated form of language activism, where the multiple meanings of Diidxazá- of language- are open for (re)interpretation and negotiation (as discussed in chapter 1). While school-based activism may be inextricably linked with notions of linguistic competence and standard language ideologies, and scholar activism is influenced by the tendency to define, categorize and assert authoritative knowledge, popular culture activism draws from a more eclectic array of social and discursive resources. Like activists in community-based education, popular culture activists have a more open space to work with, and can contemplate a wider range of potential participants and imagine alternative connections among them.

The political power of the aesthetic, creative and performative domains of life has been examined in multiple contexts (e.g. Edelman 1995), not least that of Indigenous activism. Sociolinguist Sari Pietikäinen (2018) examines the new meaning-making achieved by Indigenous Sámi activists through visual art, such as posters and re-appropriated digital images which combine elements of global culture with elements of Sámi culture. For example, the US World War II poster of 'Rosie the Riveter' is redesigned to wear iconic Sámi 
clothing, with Northern Sámi text, as a representation of Indigenous resistance. She labels this strategy "affective multilingualism”, and argues that:

For this kind of affective multilingualism to work - that is, to transform some of the existing ways of perceiving, thinking and talking about Sámi issues and creating affective solidarity, alliances and politics - requires interconnected and intertextual ways of working and the recycling and reworking of traces and signs already used before: they need to be rooted in expressive rhizomes and engage with multilingual and multisemiotic resources.

(2018: 193)

Pietikäinen points towards a two-fold goal for these activists; they aim to transform ways of perceiving and thinking, and to foster "affective solidarity", what in Mexico would be called convivencia, conviviality (see also chapters 4 and 6). She also highlights how they are able to achieve these goals through the recirculation and re-purposing of visual and linguistic resources in social space.

Such recirculating of semiotic resources is described by Bauman and Briggs (1990) as acts of entextualization, decontextualization and recontextualization. Like the Sámi activists choosing to recontextualize Sámi clothing onto a global icon of feminine resistance, the Juchirap musicians chose to recontextualize a piece of the Isthmus Zapotec literary canon (López Chiñas' famous poem) in a global musical genre, as described in the opening vignette. Bauman and Briggs note that producing chains of meaning in this way is a performative, political action. Choosing to "decenter" and "recenter" an image, text, or sound "is an act of control", subject to social limitations of access and resources (1990: 76). Activists who engage in these creative productions are part of the "the process of traditionalization, the telling and retelling of a tale, the citing and reciting of a proverb as these recenterings are part of the symbolic construction of discursive continuity with a meaningful past" (1990: 77-78). Pietikäinen calls this "the politics of becoming", noting that aesthetic activism "does not just reflect contemporary values, identities, and relationships but is an active participant in the creation and recreation of the socio-cultural milieu" (2018: 193).

The semiotic tools which popular culture activists make use of - such as images, music, and text - are also available and used by activists in other domains, but often with a more limited range of expression. While activists in higher education are negotiating the nature of the identity of 'Isthmus Zapotec teacher' (see chapter 5), popular culture activists are typically engaged in negotiating broader categories such as 'Isthmus Zapotec speaker', 'Isthmus Zapotec woman', and 'Isthmus Zapotec person'. Popular culture spaces, such as the hip-hop scene, are important sites for many kinds of activism and political engagement. In these spaces, contested identities, resources and rights may be represented and negotiated, often in intertwined ways. Language activism, 
where present, is often closely intertwined with other concerns, such as shifts in Indigenous identities and lifestyles or critiques of non-local interventions in the local society and economy. Describing the history of Isthmus Zapotec cultural promotion in the $19^{\text {th }}$ and $20^{\text {th }}$ centuries (see also chapter 2 ) in an article published in Guchachi' Reza in 1984 and reproduced in an edited volume in 1993, Istmeño scholar and writer Víctor de la Crúz noted that:

As the cultural and linguistic movement becomes politicized, its objectives broaden. Now it is not enough to recover native language and culture. It is also necessary to recover the communal lands that are being monopolized and privatized. [. . . In relation to this our history has taught us, [. . .] that we Zapotecs cannot win the battle by ourselves. We must seek new alliances [. . .] and, in this way, widen our project.

(1993: 245)

Making linguistic and cultural movements visible to members of the nonIndigenous society and showing how they are linked with wider concerns of identity and well-being is another part of the activist agenda. Elsewhere in Mexico, Indigenous language activist and scholar José Antonio Flores Farfán has discussed the value of pursuing language activism through multilimedia and art in order to build wider coalitions (Flores Farfán 2002). Producing bilingual multimedia resources is "useful to a wide audience, namely, people in the indigenous and mainstream populations looking to establish a respectful and productive dialogue between different sectors of Mexican society" (2002: 231) he argues. Whether through a range of semiotic resources, or through widened solidarity and conviviality, popular culture activism has considerable potential and power.

This activism can take many forms. In the following sections I offer a glimpse of the strategies of several popular culture activists in the Isthmus, including the hip-hop movement (7.2.1), a women's collective (7.2.2), digital spaces (7.2.3), and discuss some of the common characteristics and the wider networks which support these grassroots projects (7.3).

\subsection{Popular culture activism in the Isthmus}

There is a long tradition of locally run artistic production as well as volunteerorganized groups and initiatives in the Isthmus. From the independent publications of Neza and Guchachi' Reza, to the founding of the Juchitán Casa de la Cultura in 1972, there have continued to be a multitude of publications, radio programs, events, and cultural spaces created by Istmeños. Cultural activists have created spaces of exchange and creativity in their own homes or in public parks, and are respected and appreciated by residents of all ages. For example, 
in Union Hidalgo, a village to the southeast of Juchitán, the Galería Gubidxa [Sun Gallery] has been established and maintained by Víctor Fuentes, a teacher and writer, who hosts art expositions as well as workshops and events, often facilitated by other members of the local community. Founded in Juchitán in 2004, the Comité Melendre [Melendre Committee] has engaged in social, cultural, and educational outreach with the goal of supporting "la transformación positiva de la sociedad zapoteca" [the positive transformation of Zapotec society] through a variety of activities. One of their projects has been the Centro Cultural Herón Ríos, which has offered workshops and events aimed especially at children (see also chapter 6). ${ }^{33}$ The collective Binni Cubi [New People] in Union Hidalgo has been active producing didactic games, murals, films and other creative products which promote knowledge of local history and language (Schwab-Cartas 2018). ${ }^{34}$ A variety of virtual spaces and resources have also been created, such as a navigator and vocabulary list hosted on the "Familia Toledo" website, ${ }^{35}$ and Diidxazá learning apps for mobile phones created by students at the Instituto de Estudios Superiores del Istmo de Tehuantepec [Institute for Higher Studies of the Isthmus of Tehuantepec, IESIT].

Among these and many other spaces and groups across the Isthmus, the role that language plays varies. The valorization of Isthmus Zapotec is sometimes explicit, as the focus of instruction or the medium of communication. In some initiatives it is interwoven indirectly in the activities, events, and creations of these popular culture activists. Here I focus on several communities of practice which have been active in creating events and networks in recent years which valorize Diidxazá in both direct and indirect ways. Beginning with the tangible spaces and events created by the hip-hop and feminist communities, I then illustrate the strategies of representation and connection within virtual spaces. A focus on convivial participation is central across most of these initiatives, as taken up further in the concluding section.

\subsubsection{Wake up! Hip-hop events and representations}

Among Indigenous language activists in many parts of the world, hip-hop has been a popular medium for valorizing Indigenous language and appealing to youth (Swinehart 2012; Cru 2017). Rooted in Black American activism, this art

33 https://comitemelendre.blogspot.com/

34 https://sites.google.com/site/lubilunisa/Home

35 www.biyuubi.com 
form has lent itself well to other contexts characterized by resistance to racism and oppression (Alim, Ibrahim, and Pennycook 2008; Williams and Stroud 2013; Williams 2017). One of the first occasions where I heard Istmeño rappers was at an event in May 2014 that several rappers had organized; their publicity for the event stated that the theme was "Libertad y Resistencia" [Freedom and resistance]. The event was held outdoors next to the Guigu Bicu Nisa ${ }^{36}$ which runs in between the central section of Juchitán and its western neighborhoods. During the dry, windy season, the levels in the river had fallen very low, and the banks were wildly overgrown, covered in most places by dense grasses and brush, a few small trees holding on to the banks here and there, and a substantial amount of plastic and trash. A group of rappers had worked together to cut down the brush and grasses and to clear a space along the bank. They set up low benches with planks and cinder blocks and had built an open thatched roof structure which housed speakers, a pile of cables and some microphones. The event included performances by several rappers, in both Spanish and Zapotec, with an audience of 30-40 people stopping by to listen and a MC hosting in Spanish in between the songs. Most of the young men wore jeans, baseball caps and t-shirts often with an English logo or slogan on them. A few were painting a graffiti mural nearby. Anyone was welcome to get up and take the microphone, some of the rappers tried out new songs, rapping from their handwritten lyrics on pieces of paper. After a boy who looked younger than the rest, perhaps 13 years old, had performed a song with some obvious difficulties, the MC encouraged everyone to give him a big applause, commenting that it takes real courage to do this.

One of the organizers was Rosty (Vicente Ramirez Santiago), the rapper who had won first prize in the 2012 CASA competition (Premio CASA Creación literaria en lengua Didxazá (zapoteca)) in the category of music. His winning song was entitled ‘¡Gutaná!' [iDespierta! Wake up!] and focused on social problems and social change in the Isthmus Zapotec community. The prize is awarded each year in several categories (music, poetry, children's literature, narrative, and text based in oral traditions) by the Centro de la Artes San Augustín (CASA), a non-profit organization based near Oaxaca City. ${ }^{37}$ CASA was founded by Isthmus-born painter Francisco Toledo, the father of poet and Camino de la Iguana co-counder Natalia

36 Otter River, often called Rio de los Perros, literally Dog River in Spanish following a direct, incomplete translation from Diidxazá: Bicu Nisa (water dog, or otter).

37 CASA supports numerous artistic endeavors that raise the visibility of Indigenous languages and forms of expression in Oaxaca, including the Camino de la Iguana workshops (see chapter 6) and other literacy outreach initiatives. 
Toledo. Francisco Toledo had also helped to found the Lidxi Guendabiaani, or Casa de la Cultura in Juchitán in 1972 and was active in the COCEI movement in Juchitán in the 1980s (see chapter 2). In the following decades, he engaged in extensive arts-based social outreach from his base in Oaxaca City, including the creation of a public graphic arts library, a photography center, and numerous campaigns for socio-political issues. Toledo achieved a unique level of international and national renown, which helped his foundations and initiatives, but he remained hugely popular and was viewed by many Istmeños as intrinsically local, a defender of Oaxacan culture, land, and language. ${ }^{38}$ The CASA award gave Rosty's music, and hip-hop more generally, the symbolic backing of CASA and of Toledo, a valuable stamp of approval in both the realm of art and of Isthmus society. On the occasion of the outdoor event by the riverside in May 2014, however, Rosty commented to me that this event was organized internally, through the volunteer labor and interest of the local hip-hop community. The symbolic backing from a state-level authority such as CASA was useful, but not as important as the genuine interest and participation of the local community which was easy to observe. The same was true of the Raptivismo radio show, and other public performances I saw in several of the central parks of Juchitán. Young people in Juchitán did not need to be encouraged to attend these events, they simply turned up.

Like Toledo himself, these hip-hop events were associated with both international and local reference points, simultaneously. By appropriating hip-hop styles to express Istmeño realities through Spanish and Zapotec, these rappers created a space for new forms of expression. One of the founding members of Juchirap, Cosijopi Ruiz López articulated this powerfully in a social media post:

A todos los que dicen que mesclar dos culturas, (hip hop, y zapoteco) esta mal, o no deberíamos hacer esto, o e inclusive no les gusta escuchar el zapoteco en una rola de rap, les quiero decir con todo respeto, "no tomare en cuenta eso" yo seguiré haciendo esto, como lo he estado haciendo, despierten!!!! y a nadie habla zapoteco, ya nadie usa carreta, ya nadie usa huaraches, les propongo algo!! rescatemos nuestro juchitan! hablemos zapoteco, rescatemos las tradiciones! saludos, y bendiciones!

To everyone who says that mixing two cultures (hip hop, and zapotec) is bad, or we shouldn't do that, and or also those that don't like hearing Zapotec in a rap verse, I want to say something with all due respect, "I won't take that into account" I will continue doing that, as I have been doing it, wake up!!!! now no one speaks Zapotec, now no one

38 When Toledo passed away in September 2019 the enormous outpourings of mourning and appreciation from all corners of society included graffiti art in his honor. 
uses carts, now no one uses sandals, ${ }^{39}$ I am offering you something!! let's recuperate our juchitan! let's speak Zapotec, let's recuperate the traditions! greetings, and blessings!

(May 2014, reproduced with permission as posted)

Rejecting a purist orientation to language and culture, Cosijopi encouraged listeners to "wake up" to the changes occurring in society and to accept what he and other younger artists are offering. They know that following the same lifestyle that their grandparents did is not a possibility, whether they want it to be or not, and they are making sense of the world they find themselves in now.

Groups such as Juchirap which 'mix two cultures' have arguably been very successful in their efforts. In the years following their founding in 2014, Juchirap has made multiple music videos which they post on their social media sites, and have been the subject of multiple news stories and video shorts, gaining a wider audience and renown within the Isthmus and well beyond. Many of the news stories about them have highlighted the fact that they rap in an Indigenous language, with titles and tag-lines like 'Con rap buscan jóvenes conservar el zapoteco del Istmo' [With rap youth aim to conserve Isthmus Zapotec] (Cha'ca 2015) and 'Estos jóvenes rapean en zapoteco para preservar su lengua' [These youth rap in Zapotec to preserve their language] (Plumas Atómicas 2019) appearing in local and national news channels. They performed as part of the 2019 Guelaguetza, a high-profile yearly event held in Oaxaca City which showcases music and baile folklórico [folk dance] from different Indigenous communities in Oaxaca. They were also one of the groups invited to perform in a Septermber 2019 concert alongside wellestablished artists to commemorate the anniversary of the massive earthquakes that caused extensive damage in the Isthmus in September 2017. The concert was entitled Dxi guni' xu en Juchitán [The day the earthquake spoke in Juchitán], and was sponsored by the national government through the Ministry of Culture. These performances place them in the company of well-recognized Indigenous artists locally and nationally. From organizing their own events and grassroots performance spaces, they have been invited into officially endorsed cultural spaces and reached a wider audience.

The hip-hop events in the Isthmus attract mainly men, although some women also perform, and many women are fans. While it is not uniquely a masculine space, there is a clear gender trend within this activist community. Women are also active in redefining popular culture spaces in a variety of ways, as explored in the next section.

39 Horse or donkey-drawn carts and hand-made leather sandals are symbols of the traditional Isthmus agricultural lifestyle, both of which are still in use, but now by fewer and fewer members of society. 


\subsubsection{The granddaughters of the Binnigula'za: Feminist events and representations}

A feminist collective has been active organizing events and spaces of expression in the Isthmus, hosting a yearly Encuentro de mujeres poetas del Istmo [Gathering of female poets of the Isthmus] since 2014, and a 'Festival of Female Artists in the Isthmus' entitled Gunaa Ruzaani [Shining woman/ Woman who gives light] in 2018. One of the organizers, Aurora Cobon, explained in an interview in January 2018 that these initiatives were organized and facilitated by a collective of around 20 women, most in their 20s and 30s, and were designed to give a space to the many female writers and artists in the Isthmus who are lesser known than their male counterparts. Through the strategy of creating events, this collective has supported connections and networks among female artists. Furthermore, they have contributed to representations of Istmeña women, which, similar to the representations produced by the rappers, are a vibrant mixture of tradition and contemporary realities.

Many of their promotional materials evidence their local-global orientation, as well as their critical focus on the current moment as a product of colonial histories. For example, the poster for the 2018 Festival of Female Artists (Figure 21) takes an image from the classic European art canon, the armless Venus de Milo at the top, giving it first arms in the middle image, and then brown arms holding a paintbrush in a strong pose in the bottom image. A yellow circle initially highlights the head and upper torso of the armless woman in the top two images, and then moves to highlight her hand and paintbrush in the bottom image, shifting from a focus on a helpless female body to the action and authorship of the woman. This symbolic empowerment of Venus through gaining brown arms and a means of expression is coherent with the aims and vision of the collective which seeks to shine light on the skills of female creators in the Isthmus. They represent Istmeña artists as part of an international art milieu, their strong arms helping to change the gender imbalance not only locally, but internationally by lending a hand to the helpless white Venus.

With bright colors and asymmetrical geometric shapes, the poster also presents a youthful, irreverent aesthetic. The organizers are listed towards the bottom of the poster, and the symbols of the organizers and collaborating hosts are aligned along the foot of the page. One of the organizers is named Las nietas de lxs Binnigula'za [The granddaughters of the [male and female] Zapotec Ancestors]. This name combines standard Spanish (the granddaughters of) with a gender neutral $3^{\text {rd }}$ person determiner (lxs) which has been popularized by gender activists throughout the global Spanish-speaking community as a way to avoid the standard practice of defaulting to a masculine form whenever both 

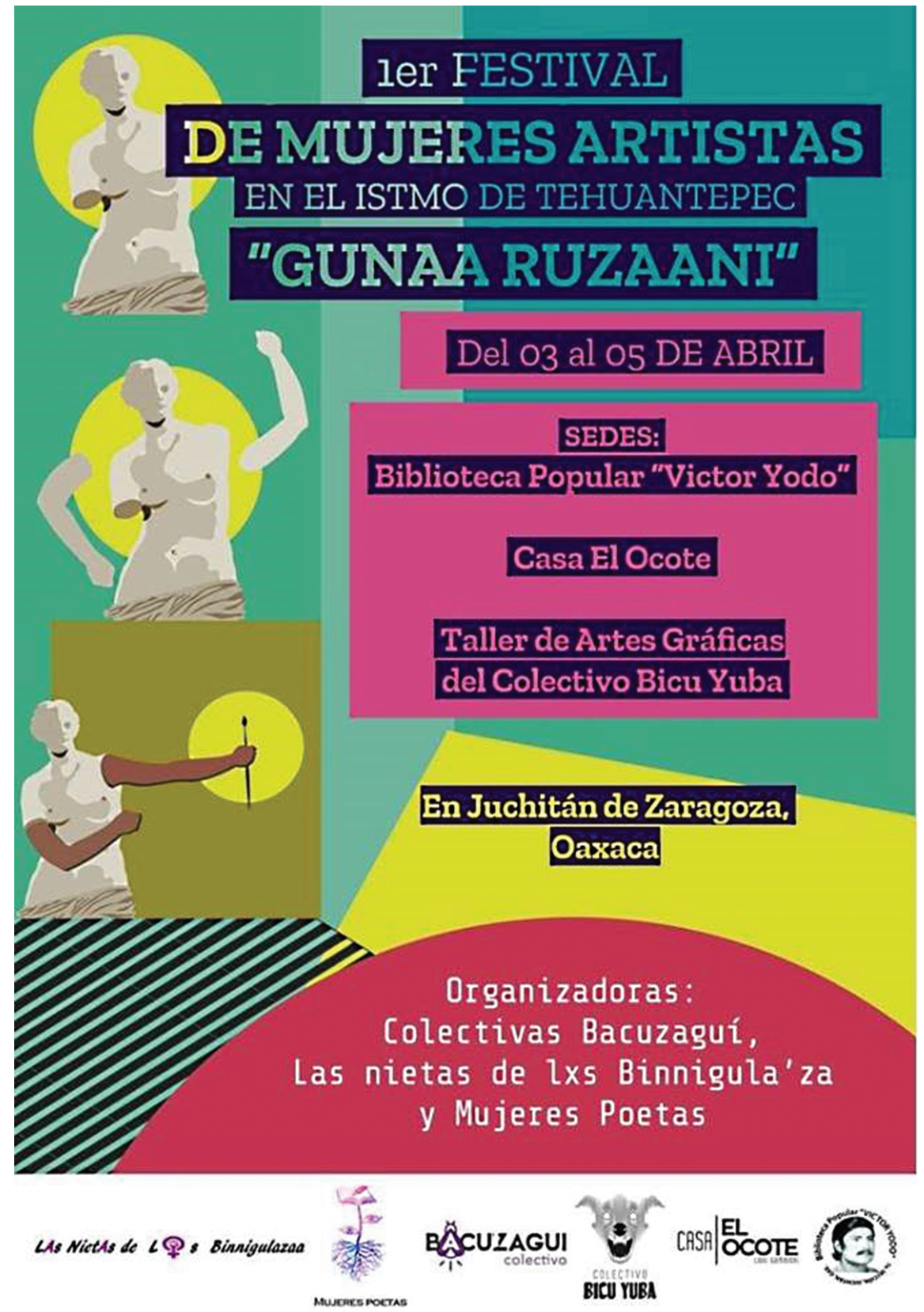

Figure 21: Poster for the "1st Festival of Female Artists in the Isthmus of Tehuantepec "Gunaa Ruzaani"' 3-5 April 2018. 
males and females are present (in this case standard Spanish would require the male determiner los). The final word, binnigula'za, is Diidxazá, and means roughly Zapotec ancestors or figures that are significant in pre-colonial mythology and spirituality. These young activists demonstrate their ownership of both Spanish and Diidxazá, and signal their explicit feminist stance through this name. They skillfully represent themselves as the descendants and inheritors of an ancient tradition, who are also intent on commenting on and improving today's unequal gender practices.

Although the patriarchal dominance which these young women resist is perpetuated on multiple fronts, the religions imposed through European colonization and the racial hierarchy which persists through coloniality in the Americas are central factors (Lugones 2016; Mendoza 2016). The feminist agenda is therefore also a decolonial agenda in many ways. While none of the young women in the collectives believe that the precolonial past was free of gender hierarchies, there is a widespread perception that Isthmus Zapotec society has been, and to some extent still is, matriarchal, with more respect granted to women than the norm of mestizo Mexican society (Poniatowska 1993; Taylor 2006). As Campbell noted, there is a "rich community oral tradition and national mythology about 'matriarchal' Zapotecs that continues to shape both local and external perceptions of Isthmus women" (Campbell 1993:89), a stereotype which I observed clearly several decades later. Additionally, Diidxazá does not distinguish between male and female gender; humans, animals and things are distinguished grammatically, requiring different determiners and verb agreement, but there are no sub-categories within the class of humans. In comparison to Spanish, which distinguishes not only between male and female humans, but assigns all objects a gender of male or female, Diidxazá allows for much more gender neutral communication practices. The fluidity of gender categories in Zapotec culture is also illustrated by the presence, and more-or-less mainstream acceptance, of muxes, or men who prefer female tasks, clothing, and male partners. ${ }^{40}$ It is therefore not surprising that local language and culture are given value and taken up as part of the struggle for gender equality by Istmeñas. Language reclamation is not their central goal, but the promotion of Isthmus Zapotec poetry, music, and visual motifs is central in their projects and it is not a coincidence that Isthmus Zapotec names were chosen for several of the collectives and for the festival itself. In this way this group has contributed to a positive, contemporary image of Isthmus Zapotec language, linking it to a

40 Gender in the Isthmus is a complex topic which cannot be fully explored here, but has been taken up elsewhere (e.g. Royce 1991; Miano Borruso 2002; Taylor 2006). 
youth-led feminist movement and aspirations for gender equality. More importantly, they contribute to representations of Istmeñas as authors and artists, and help to create spaces for expression and exchange.

All of the organizers and hosts of the 2018 festival were Isthmus-based, volunteer-run organizations. ${ }^{41}$ Each engages in their own creative endeavors, but they also showed solidarity with the feminist groups spearheading the festival, providing space and assisting with activities. This kind of collective support of large-scale events - whether the yearly saints' Velas, or a wedding or birthday is common, so much so that multiple terms exist for it. Collaborative labor was often described as tequio or trueque (terms for voluntary collaborative work which are used across Mexico) or occasionally as guendalisaa (an Isthmus Zapotec term for the action of doing relationality/ solidarity/ kinship) by the people I spent time with in the Isthmus. While local groups would not necessarily be opposed to support from larger organizations outside the Isthmus, they generally do not need such support in order to mobilize a considerable amount of resources and people. All of the workshops and performances throughout the 3 days of the festival, including workshops in visual art and creative writing, and a rap workshop led by Oaxaca City-based rapper Mare Advertencia Lirika, were free for participants and female participants were given first priority to attend.

The participatory events organized by the hip-hop and feminist communities attract the attention of adults and younger people in the Isthmus. They are both driven largely by young adults, although they seek and appreciate recognition and support from pre-existing organizations and networks where possible. By positioning themselves as simultaneously traditional and modern, local and global, they have achieved a successful, convivial form of activism. Collaboration or guendalisaa has been central to these endeavors, building on local social networks for material and intangible forms of support. The circulation of images, music and text through mass media and social media is also central to the practices of the groups described above, as they seek to promote and invite participants to their events, and reach wider audiences through on-line networks. In the following section I examine the role that digital spaces play in facilitating language activism in the Isthmus.

41 The other organizers are Colectivas Bacuzagui (Firefly collectives) and Mujeres Poetas (Female poets), who were supported and given physical space for the festival by Colectivo Bicu Yuba (Mad/ rabid dog collective), Casa El Ocote (a cultural center named after a Mexican pine tree) and the Bibliotheca popular Víctor Yodo (Víctor Yodo people's library, a library established and maintained by the family of a well-known Juchitán Indigenous rights activist who was disappeared in 1978 during the COCEI movement (see chapter 2)). 


\subsubsection{Creating virtual resources and spaces of negotiation}

The virtual space of social media and digital communication is a significant part of most people's lives in the Isthmus, and numerous language activists have engaged in strategic use of these resources to promote Diidxazá. "Digital activism" has been a topic of investigation and admiration in multiple Indigenous communities (Coronel-Molina 2019). The use of technology in service of Indigenous activism builds on a well-established tradition of Indigenous language radio in the Americas dating back several decades. Isthmus Zapotec radio has been active since the 1970s (Campbell 1989) and several radio stations continue to produce substantial programming in Diidxazá. Radio Totopo, based in the southern $7^{\text {th }}$ section of Juchitán, broadcasts only in Diidxazá and has also served as a base for political activism around community rights, in particular resistance to the wind farm developments (Sánchez Miguel 2016). Coronel-Molina (2019) notes that considering the achievements of Indigenous language radio, the use of Indigenous languages in the mass media is not new. However, he argues that "media and technology are contributing to the creation of new hybrid, heteroglossic cultural and linguistic forms through complex interplays between virtual and real communities in contemporary times. Virtual spaces are multilingual, pluricultural, multiethnic, translingual, transcultural and translocal" (95). This contrasts with the communication produced by radio stations such as Radio Totopo, which is entirely in Diidxazá. Coronel-Molina (2019) points out that there are important asymmetries and hierarchies within these multilingual virtual spaces, which minority language activists must attempt to address.

Digital language activism includes trying to address virtual hierarchies and the so-called digital divide by making more information available in Indigenous languages, as well as providing infrastructure for people to use Indigenous languages in the media that are part of their everyday communication practices. In relation to the former, there have been several initiatives to create on-line as well as app-based vocabulary lists and translation resources for Isthmus Zapotec, including an on-line audio vocabulary of Juchitán Zapotec created by the non-profit group Fundación Historico Cultural Juchitán ${ }^{42}$ [Historical Cultural Foundation of Juchitán]. This group, another volunteer-driven collective, was founded in 2003 by elder men from Juchitán with the aim to "preservar y fortalecer nuestra identidad histórico-cultural" [preserve and strengthen our historical cultural identity] (Fundación Historico Cultural Juchitán website). The website that they created presents a clear historical aesthetic, with a parchment-style

42 www.zapotecoteco.org.mx 
background and a logo that represents a pre-colonial sculpture found in the Isthmus which is now on display in the National Museum of Anthropology in Mexico City. Aside from a Spanish-Zapotec translation function and audio samples of words in Juchitán Zapotec, the site also contains "Homenajes" [Homages] giving biographies and images of 10 men from Juchitán who they view as having made a mark in politics or in the cultural sphere. The site also contains multimedia (historical photographs, music, and documents), and the group has created several YouTube videos. One of the founders, retired educator David Ruíz Martínez, discussed the importance of representing Zapotec on a par with other languages, noting that many young people have been socialized to have "ese complejo de creer que ser indígena es ser tonto, ser torpe, ser mediocre" [that complex of believing that to be Indigenous is to be stupid, to be clumsy, to be mediocre] (Interview April 2014). He and the other members of the group are committed to countering these stereotypes through highlighting the history behind the language and the participation of Istmeños in high status social domains such as politics, science and culture. He argued that Zapotec needs to be used more in higher education, and saw the website as a small contribution towards representing Zapotec as a language of literature, science and philosophy. As language and cultural activists, this group had a strong focus on the past, but by choosing to develop digital resources they illustrated their desire to engage with a wide audience in the present and to bridge from the traditions that they grew up with to the society around them today.

This was an apt choice; people (especially young people) who want to gain more knowledge about Isthmus Zapotec often turn to the internet as a source of information and authority. On-line dictionaries, translation apps, and thesaurus have become the resource of choice for many writers. A young adult university student commented on how useful some of the Zapotec resources are for her:

A mí me gusta publicar también en Facebook cosas en zapoteco entonces no podía estar llamando a mi mamá cada que yo quisiera [subir algo en zapoteco] entonces cuando me surgen dudas así voy al buscador de google que es el más bueno y busco cosas nuevas. Entonces en esa búsqueda encontré un diccionario en línea de español a zapoteco, no hay de zapoteco a español, pero sí de español a zapoteco. Entonces escribes lo que quieres saber y te aparece la pronunciación. También en YouTube hay lecciones de zapoteco es un usuario que se llama Tehuanos76 algo así pero ya tiene muchos videos tiene como ciento y tantos videos de. . .zapoteco.

I like to publish things in Zapotec on Facebook also, so I couldn't be calling my mom every time I would want to [post something in Zapotec], so when I have doubts like that, I go to the Google search that is the best and I look for new things. So in that search I found a Spanish to Zapotec on-line dictionary, there isn't one from Zapotec to Spanish, but yes Spanish to Zapotec. So you write what you want to know and the pronunciation appears for you. Also 
in YouTube there are Zapotec lessons, it's a user that is called Tehuanos76, something like that, there are many videos, there are like a hundred or so videos of. . . Zapotec.

(Interview October 2013)

For some people, such as this young adult, the use of Zapotec in texting or social media posts is a natural thing, representing the significant place of Zapotec in their communicative repertoire. Depending on their interests and abilities, some turn to on-line resources as a way to find new words, to check their spelling, or even to learn pronunciation through video and audio resources. The somewhat static resources such as word lists and videos are thus directly linked to and supportive of more communicative and fluid use of Zapotec, such as social media posts and conversations. While not everyone who uses Zapotec in social media does so with an activist agenda, their practices help to make up the language ecology in the Isthmus and thus carry a political significance. Some people choose to post in Zapotec due to their stance in support of the language, while others may choose their language(s) for practical, aesthetic or semantic motivations. Resources that can enable these multimedia communication practices are important supports for the normalization of Isthmus Zapotec in the contemporary communicative landscape.

As discussed in previous chapters $(2,4,6)$, most Istmeños have not had the opportunity to learn the Isthmus Zapotec popular alphabet, and instead they write drawing upon their Spanish literacy. Some people are not concerned with following a writing norm, while others express a desire to improve their ability to write in Zapotec. Perhaps exacerbated by this, there is a considerable amount of meta-commentary about Diidxazá, Diidxazá competence, and Istmeño culture that occurs on social media, such as the meme shown in Figure 13, section 5.1. Negotiating competence through discussions of spellings and translations can occur in public and private conversations, and multiple pages and profiles exist in social media to disseminate information about the language or culture. One example of this kind of activist social media site is a Facebook group called $\mathrm{Gu}$ ca’nu jneza diidxazá [Let’s write good Diidxazá] that was founded in March 2014. This initiative was started by León Medellín, a young man from Union Hidalgo in the Isthmus, who spent many of his formative years outside the region due to his family's economic migration. He was motivated to learn Isthmus Zapotec spelling norms himself, and to engage others in discussion and awareness-raising about the writing practices in the region. Discussing writing practices, he argued:

Hay que unificarlo porque yo al rato escribo un libro en zapoteco, y fulanito escribe otro, y al rato se va a hacer una antología de escritos en zapoteco. Y si no hacemos todos el mismo esfuerzo del mismo lado, pues a la hora que nuestros nietos, nuestros bisnietos y tataranietos 
quieran agarrar esa información, pues se van a ver en un mar de complicaciones [. . .] Entonces esa es la finalidad del, de la ortografía, ¿no? Que pueda, se pueda este, conservar. Conservar la literatura y conservar la lengua, ¿no?

It must be unified because in a bit I'll write a book in Zapotec, and so-and-so writes another, and in a bit an anthology of writing in Zapotec is going to be made. And if we don't all make the same effort from the same side, well when our grandchildren, our greatgrandchildren and great-great-grandchildren want to get a hold of that information, well they will find themselves in a sea of complications [. . .] So that is the final goal of, of orthography, right? That one can, one can, um, conserve. Conserve the literature and conserve the language, right?

(Interview May 2014)

When asked about the possible paradox between conserving the diversity present within the Zapotec speech community (such as the dialect variants) and unifying the writing system (which would mean less diverse writing practices and potentially disadvantage for some dialects), he responded that the variation was not so great, and a common writing system was the most important goal, allowing Zapotec to be read in the future in the way that Greek texts are still read today. His intention was to both present a unified view of Isthmus Zapotec orthography, and to assist in the production of writers (of a standard variety).

León considered an open social media group to be an appropriate way to achieve his goals, explaining:

León Hice ese grupo principalmente para que a la gente que le interese escribir en zapoteco pueda este, pueda ir enseñando. Y además es abierto, ¿no? Es abierto para que cualquiera publique, como foro de discusión. Es decir, bueno, "yo lo escribo así porque aquí dice que así se escribe." "No, pero yo pienso que"- así y ahora viene esta nueva norma que se va a escribir así. "Ah, bueno. ¿Entonces cómo va a quedar?”

HDK Hum.

León Como un foro de discusión. Sin embargo, no ha tenido tanta repercusión como he querido, pero, pero sí lo hago y yo publico mucho en ese lugar sobre [. . .] las grafías del zapoteco. Para que la gente también se entere cómo es.

León I made that group principally so that people who are interested in writing in Zapotec could um, could be teaching. And additionally it's open, right? It's open so that anyone can publish, as a form of discussion. That's to say, right "I write it like this because here they say that it's written like this." "No, but I think that it's like this" and now comes this new norm that it's going to be written like this. "Ah, OK. So how is it going to turn out?”

HDK Hmm. 
León Like a discussion forum. However, it hasn’t had as much repercussion as I had wanted, but, but yes I do it and I post a lot in that place about [. . .] the Zapotec graphemes. So that people also find out how it is.

(Interview May 2014)

This Diidxazá activist imagined the homogenization of Zapotec writing as a necessary goal which he hoped to achieve through convivial interactions and discussions. He attempted to foster a community of practice among people who are voluntarily interested in Zapotec writing norms. The public participation was not as lively as he had hoped in the beginning, and the group has not always remained tightly focused on writing, but has rather become a space of general interest in the language, including sharing texts, news articles, and events relevant to Isthmus Zapotec (as of November 2020 there are 1,731 members). Representations of Diidxazá as a language (not a dialecto) and pan-Zapotec ethnic pride have also been common on the page. Considering the kinds of posts and discussions on the page, most members seem more (or at least equally) interested in language use, history and culture, than they are in discussing language norms.

Another way in which meta-commentary about Zapotec circulates in cyberspace is through humorous memes and comics produced by both individuals and by group pages. Memes often recycle images and texts from one context to another (Wiggins and Bowers 2015), creating the kind of juxtaposition and recontextualization which can lead to new perceptions as discussed by Bauman and Briggs (1990) and Pietikäinen (2018). There are several Facebook pages where Isthmus-specific memes are posted and often recirculated. One example is the public page Nanixhe \& Guendanayahui [Sabroso \& [hacer] chistoso, delicious and being funny] which publishes a wide range of memes and commentaries in relation to many aspects of life in the Isthmus, the vast majority with humorous content. This page (founded in 2014, with over 9,000 followers as of November 2020) does not have the explicit pedagogical approach present in the Guca'nu jneza diidxazá [Let's write good Diidxazá] page. However, the moderators of the page were motivated to post an explicit encouragement to people who are making memes that they should use the popular alphabet, and the pedagogical grammar and vocabulary produced by SIL (based on the work of Velma Pickett and her collaborators, see also chapter 3). They provide links to these resources and state that meme-makers should avoid fragmenting the language. They take a light, but direct tone, writing "Invitamos a todos aquellos que hacen memes, que aman y hablan la lengua zapoteca a que hagamos un pequeño esfuerzo, -además, nadie quiere decirle víbora a su hermana-." [We invite everyone who makes memes, who loves and speaks the Zapotec language 
to all make a small effort,- additionally, no one wants to call their sister a viper-.. ${ }^{43}$ (June 2019).

Language ideologies are present in some of the memes that are circulated as well. Figure 22 shows a meme which was produced by a different page, Memes Idiomas UABJO [Memes for/ from the UABJO Faculty of Languages] and reposted on Nanixhe \& Guendanayahui in November 2018, which represents different languages as superheroes fighting over superiority. The first frame shows a blue character with a head-band saying in Spanish and (globalized) Japanese "iJaponés es la lengua más kawai! ¡Muere, baka!” [Japanese is the most kawai [adorable] language! Die baka [stupid]!]. In the second frame a green character with a mohawk lunges forward yelling in French-accented Spanish “iNo, Fgancés es la mejog! iMuege!” [No, French is the best! Die!]. In the third frame a significantly more powerful character has impaled both of the fighters on swords, while yelling

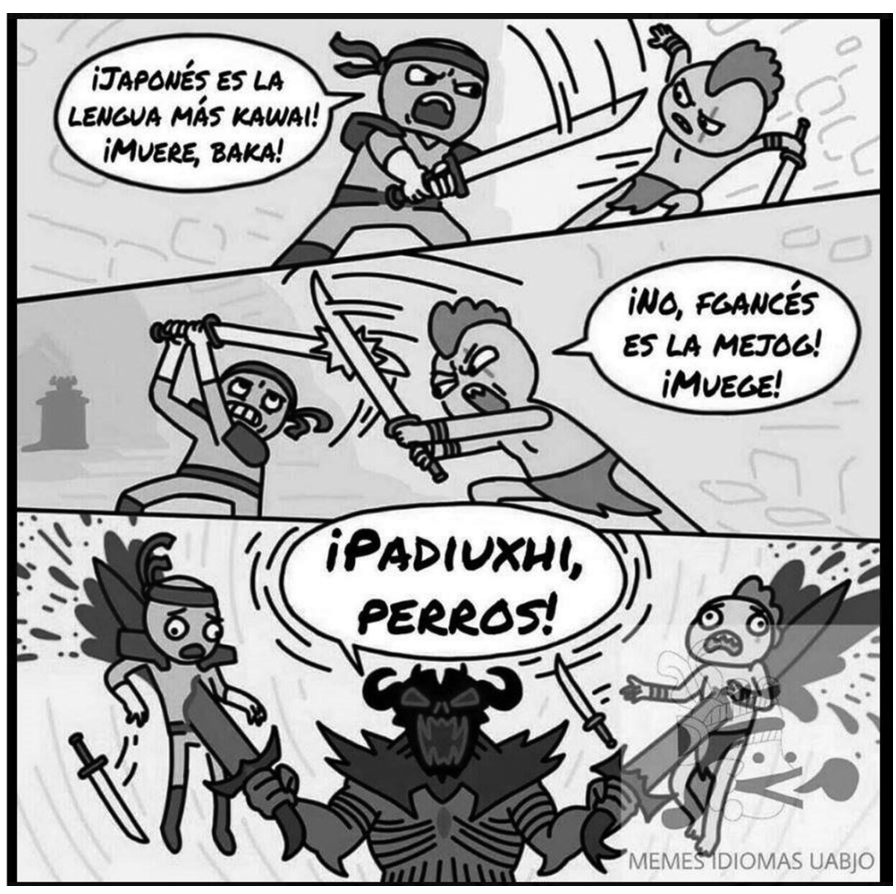

Figure 22: Meme from the page Memes Idiomas UABJO, 2018.

43 This refers to a minimal pair (or trio) in Diidxazá, the words for benda' (my sister), beenda' (snake/ viper), and benda (fish). 
in Isthmus Zapotec and Spanish “iPadiuxhi, perros!” [Hello, dogs!]. The comic meme implies that Zapotec is infinitely superior to both Japanese and French, a message that many are likely to understand as the greeting 'Padiuxhi' is often recognized also by people who do not speak Isthmus Zapotec.

The examples of pedagogical and social uses of Diidxazá in multimedia channels discussed here are only a glimpse of the variety of initiatives and practices which digital language activists have created. On one hand these social media practices reflect and reproduce Zapotec communication among those who already use it in their daily lives. For example, the blending of different languages, or translanguaging, as illustrated in the meme in Figure 22, is common both in face to face conversation and in digital forms of communication. On the other hand, these practices are also often intended to bring about change in the speech community, for example through the (positive) ways that Indigenous languages are represented, the new resources made available, and/ or the norms that are modelled and encouraged.

\subsection{Summary: Characteristics of popular culture activism}

The people who participate in the fluid spaces of popular culture initiatives are deeply engaged in the politics of language and identity in the Isthmus, albeit in many different ways. Like community-based education activists, popular culture activists have extensive scope to imagine new ways of being. The strategies which these activists employ range from the promotion of a pure, prestigious variety of Diidxazá, to recontextualizing Diidxazá for the purposes of humor and commentary. Some activists use the language and culture as a tool to critique socio-economic, racial, and gender inequalities - as well as linguistic inequalities. Popular culture activism is characterized by a high level of open participation, whether in the tequio needed to produce local events or in the creation and recirculation of information and images on-line. The voluntary collaborations within the hip-hop community, the feminist collectives, and the digital activists all illustrate the value placed on convivencia and participation by language activists in the Isthmus. Like the Indigenous activists described by Pietikäinen (2018), their strategies combine "resistance and compassion in an attempt to develop creative, alternative and critical considerations to existing, powerful and often ideologically fixed views on identity and its categories” (193).

Some of the key activism strategies in popular culture spaces are illustrated in Table 6. The young musicians, poets and meme-makers are engaged in creating events and spaces where there is place for their local-global identities. Their acts of linguistic citizenship (Stroud 2018) go beyond promotion of language, to 
include understandings of identity and the contemporary community. Popular culture spaces largely represent multilingual, pluralist communication practices as a norm, although these spaces can also be used to open debates about norms and standards, as discussed above. In most cases, popular culture activism ties together different ends of the strategy characteristic scales, drawing on local and global references and forms of support, and linking the past with the present. A majority of initiatives are also oriented towards pluralist or syncretic language use, although there are expections. In all of these initiatives, a relatively high degree of open participation is present and explicitly recognized by the initiators as a key to the success of the endeavor.

Table 6: Key language activism strategies in popular culture initiatives.

\begin{tabular}{|c|c|c|}
\hline Actions $\rightarrow$ & Goals $\rightarrow$ & Examples \\
\hline - Creating & $\begin{array}{l}\text { - Events } \\
\text { - Spaces/ Structures }\end{array}$ & $\begin{array}{l}\text { - Performances and festivals which } \\
\text { focus on local participation and draw } \\
\text { on multilingual repertoires } \\
\text { - Radio shows, yearly events, social } \\
\text { media pages }\end{array}$ \\
\hline - Representing & - People/ Identities & $\begin{array}{l}\text { - Local-global and traditional-modern } \\
\text { identities } \\
\text { - Anti-colonial and anti-patriarchal } \\
\text { identities } \\
\text { - } \text { High status local artists and } \\
\text { intellectuals }\end{array}$ \\
\hline - Representing & $\begin{array}{l}\text { - Communication } \\
\text { practices }\end{array}$ & $\begin{array}{l}\text { - Promotion of pluralist, multilingual } \\
\text { communication as a norm } \\
\text { - Promotion of standard writing } \\
\text { norms }\end{array}$ \\
\hline
\end{tabular}

Additionally, popular culture initiatives often emerge and evolve at a speed and with a fluidity that many of the institution-based forms of activism cannot match. Organizing an event or festival, or writing a new song, are likely to take a substantial amount of time, but sharing images and music after the fact, recirculating memes, and engaging in digital language politics can happen very rapidly. This speed and flexibility allows for adaptation and sensitivity to context, as well as building on the contributions of participants. At the same time, not all of the popular culture initiatives that emerge in the Isthmus achieve longevity-some do not aim to do so. The shorter, faster timeframe of popular cultural activism may lead to it being overlooked, or its results being harder to ascertain 
that the slower, more explicit forms of change in educational institutions. However, the potentially wide reach of the messages and content created by popular cultural activists make them of undeniable importance. Ways of representing Diidxazá in memes, websites or songs tend to be fairly visible or accessible and rapid in comparison with other strategies, such as representing the language in a classroom or institution. This does not mean that such representations are ephemeral, however, as they may build up over time and help to establish new ways of thinking and viewing the world.

New perspectives emerge from the recontextualizations in the music, art, and digital media that popular cultural activists create. These "chains of decentering and recentering" (Bauman and Briggs 1990: 78) create links beween history and the present, and between the local and the global. David Ruíz Martínez, one of the founders of the Fundación Historico Cultural Juchitán, was hopeful that new links between the local context of the Isthmus and the language ideologies present in other parts of the world are supporting a change in attitude and in cultural norms. He commented:

Pero ahora está surgiendo como--- [. . .] una neoculturación zapoteca. Como que está habiendo una--- un despertar de nuestra niñez, de nuestra juventud, de nuestra--- de nuestros adolescentes. Porque han visto que al llegar a otras universidades, a otras instituciones de educación superior, no solamente del país sino de otros países, donde se valoran muchísimo las lenguas originales. $Y$ en ese momento se quedan. . . jsorprendidos! [. . . 'Bueno, entonces. . . no es tonto el que habla el zapoteco, es un hombre sabio, ¿verdad?’ Porque prueba de ello ahí está, Chico Toledo, un gran pintor.

But now there is like--- [. . .] a Zapotec neo-enculturation emerging. Like there is happening a--- an awakening of our children, of our youth, of our-of our adolescents. Because they have seen, when arriving at other universities, other higher education institutions, not only in this country but in other countries, where original [Indigenous] languages are greatly valued. And in that moment they stop and feel. . .Surprised! [. . . ' 'Alright, so . . . he who speaks Zapotec isn't stupid, he's a wise man, right?' Because a proof of it is there, Chico Toledo, ${ }^{44}$ a great painter.

(Interview April 2014)

Referring to Francisco Toledo as an example of a speaker of Zapotec who has gained international renown, Ruíz Martínez observed that more young people seemed to see Zapotec as a sophisticated language with an illustrious history and which is respected globally. Representing role-models such as this in a globally accessible digital space is one of the strategies that he and his collaborators use to promote positive representations of Isthmus Zapotec language and speakers.

44 Chico is the nickname or shortened version of Francisco. 
The female poets, artists, and hip-hop musicians in the Isthmus today are quickly becoming role-models for the generations that are growing up under them. The messages broadcast by the young rappers and feminist collectives have also valorized local language and identity within global frames of reference, albeit with a different tone and style. Members of these groups all articulate the need to recognize and deal with the changes and inequalities which they see around them, one of which is the prejudices against Indigenous language speakers. They often reference their predecessors with respect, and gesture towards the literary and artistic lineage that they are building upon, for example in citing deceased poets and labelling themselves the 'granddaughters of the Zapotec ancestors'. At the same time, they do not hesitate to make their own marks that are unique to the contemporary moment, to recirculate and recontextualize everything from memes and images to words and identity categories. As Aurora Cobon, one of the organizers of the feminist collective, commented "Otras generaciones se organizarón en su tiempo, ahora es de nosotras" (Other generations organized themselves in their time, now is for us) (Interview January 2018). 